\title{
Does issue alignment matter? The electoral cost and reward of agricultural representation in urban and rural areas
}

\begin{abstract}
There is plenty of evidence that legislators think that aligning with voter preferences benefits their re-election. But whether or not legislators are constrained by demand, we have limited knowledge about. This article tests if issue representation in a generally salient field affects the legislators' electoral performance. The analysis uses data from five consecutive Hungarian elections (1994-2010), and investigates the effect of agricultural interpellations on the legislators' vote shares under varying district demand. Findings indicate that congruence between district demand and legislator action matters when the issue is of great salience, and during times of anti-party sentiments within the electorate. While more interpellations are rewarded in rural districts, MPs can lose a lot of votes by asking agricultural interpellations in an urban area. At the same time, not submitting interpellations in rural constituencies does not result in similar vote loss. Results suggests that for re-election seekers taking action is the way to go only if it is calibrated to district demand.
\end{abstract}




\section{Introduction}

Students of legislative behaviour often consider legislators as 'single-minded seekers of reelection' (Mayhew, 1974). Members of Parliament (MPs) believe that their actions have an electoral impact, and organize their activities so that it maximizes their chances for reelection. Even though they may pursue re-election through a number of ways, issue representation has always been one of the most important phenomena researchers look at.

'Policy responsiveness' (Eulau and Karps, 1977), 'congruence' (Miller and Stokes, 1963) or 'concurrence' (Verba and Nie, 1987) appears when there is a strong correlation between constituent opinion and what governments, parties or legislators do in office. If citizens pay attention to the legislators' policy performance, re-election seekers must align with voter preferences (Ferejohn, 1986; Söderlund, 2008; Woon, 2012). This means that to some extent, MPs are 'constrained by constituent demand' (Norris, 1997). Although legislators are often torn between the dissimilar interests of their competing principals such as party leaders and constituents (Carey, 2007; Kirkland and Harden, 2016; Rosas et al., 2015), and party leaders exert great influence by controlling candidate access to the party label (re-selection) and to various resources and positions, considerable literature demonstrates that parliamentary action aligns with citizen preferences too (Costello et al., 2012; Maestas, 2000; Roberts and Kim, 2011; Sorace, 2018; Thomassen and Andeweg, 2004). Clearly, legislators think that doing so benefits their re-election. But whether or not legislators are indeed constrained by demand, we have limited knowledge about. Do policy actions really have an effect on re-election? Does issue representation in a salient field affect legislators' electoral performance?

The literature of retrospective voting largely builds on the sanctioning and the selection models of representation. While the sanctioning model argues that voters try to minimize moral hazard, and re-elect only high-performing parties and politicians (Barro, 1973; Ferejohn, 1986; Key, 1966), voters in the selection model aim at electing competent leaders with high integrity (Fearon, 1999; Mansbridge, 2009). However, whereas voters may try to avoid moral hazard and adverse selection, cognitive and emotional biases can hinder effective accountability. Accordingly, Healy and Malhotra (2013) operationalize retrospective voting as a four-step process. (1) Voters observe politicians, parties and policy actions, (2) they attribute responsibility for these actions and outcomes, (3) they evaluate the performance of those with the responsibility, and cast their votes accordingly, and finally (4) the voters' electoral behaviour creates the incentives for parties and politicians, and consequently 
influences policy actions (Healy and Malhotra, 2013). The reason why policy actions do not necessarily translate into reactions is that voters sometimes make mistakes at the stages of observation and attribution. Additionally, sometimes the respective policy action is just not relevant to the voters, leaving legislator effort unrewarded.

This article joins into the process at the step of performance evaluation, and analyses election results as a function of legislator behaviour and district preferences. Legislators who demonstrate being aware of local problems, and show willingness to use their limited resources to address them are perceived as 'good' representatives by the voters, and as a result increase their vote share. At the same time, engaging in an issue irrelevant for the district may hinder re-election by sending voters the wrong message. A mismatch between issues advertised by legislators and district preferences is not only useless for achieving re-election, but it might even worsen electoral performance. Advocating the wrong issue may rapidly alienate voters by painting the picture of legislators who ignore the constituency angle of their work, and pursue the representation of alternative interests.

The analysis uses data from five consecutive Hungarian elections (1994-2010), and investigates the effect of agricultural interpellations on the legislators' single-member district (SMD) vote shares under varying district compositions. The rural-urban cleavage is one of the most basic political divides and, though in new forms, it still shapes both divisions in society (Ford and Jennings, 2020; Kriesi, 1998) and political preferences (Kelly and Lobao, 2019). Therefore, thematising agriculture is an important means of vote-seeking in rural areas. Importantly, although a number of studies focus on issue representation and issue voting in Eastern Europe (Roberts, 2009; Roberts and Kim, 2011; Tóka, 2002), the electoral effects of policy representation have not yet been tested in these countries. The article concludes that issue alignment affects vote share when the issue is of great salience, and when political turbulence deprives government parties from their former supporter base, which then in turn enables personal vote aspirations to succeed. Regression results suggest that voters positively react to agricultural representation when it aligns with district demand, and importantly, a mismatch between legislator activities and district preferences rapidly worsens electoral performance.

\section{Theoretical framework}




\section{The electoral reward of issue representation in parliament}

There is considerable research on how voting in the US Congress affects the legislators' vote shares. Serra and Moon (1994) argue that responsiveness matters at the ballot boxes: even though voters expect service responsiveness (such as casework) and it plays a key part in voter decisions, it does not entirely substitute policy responsiveness. To maximize electoral performance, incumbents must find a balance between various types of activities, such as constituency work and issue representation in the legislature. Importantly, representatives believe that their roll call decisions influence how they perform at the elections (Clausen, 1973; Kingdon, 1989; Sullivan et al., 1993).

But do voters respond to roll call behaviour? On the one hand, voters do not sympathize with party soldiers. There is evidence that the more representatives support their parties' positions at roll call, the lower their vote share at the next elections (Bovitz and Carson, 2006; CanesWrone et al., 2002; Carson et al., 2010). On the other hand, voters reward roll call behaviour that aligns with constituent opinion. Abramowitz (1988) finds that the members' voting records leads to significant vote loss at the Senate elections when it is not in congruence with district ideology. More recent results show that Democratic supporters of the health care reform are perceived as ideologically distant by the voters, and lose votes as a result (Nyhan et al., 2012). Similarly, Bussing et al. (2020) demonstrate that while Republican legislators do not seem to respond to constituent opinion at the 2018 health care vote, voters were more likely to support the incumbents who voted in line with voter opinion. Furthermore, survey data suggests that American voters have crystallized preferences over bills, they correctly estimate the legislators' voting behaviour, and hence effectively hold the representatives accountable for their votes in Congress (Ansolabehere and Jones, 2010). At the same time, there is evidence that accountability only works under specific circumstances. Rogers (2017) for instance shows that where legislators have less media attention, have larger staff and in more partisan districts state legislators do not face electoral consequences for how they voted.

Outside the US, there is a hiatus in the literature explaining the electoral chances of individual candidates dependent on their policy choices. Instead, authors are interested in overall party performance as a consequence of the parties' positions in the policy space. The focus is on whether or not the parties' closeness to the median voter's preferences in European multiparty systems has similar effects than in the US' two-party system. Most prominently, analysing the electoral performances of 80 parties in Western Europe between 1984 and 1998, 
Ezrow (2005) finds that parties closer to the median voter perform better at the elections. Ezrow's findings support Schofield's (2004) stochastic models, Lin et al.'s (1999) theoretical contribution, as well as Alvarez et al.'s (2000) analysis of the 1987 British general elections.

\section{Parliamentary questions as means of issue representation}

Most of the US literature makes use of roll call records to measure incumbent positions in the policy space. At the same time, due to disciplined parliamentary parties, this measure would not reflect the accurate position of legislators in Europe (Thomassen and Andeweg, 2004). In most European parliaments, MPs have other means to represent policy interests without breaking party unity. Contrary to roll call that manages issues already on the parliamentary agenda, parliamentary questions allow MPs to set the agenda themselves. Parliamentary questions are primarily regarded as mechanisms of government accountability: legislators use questions to control government action. However, as frequently argued in the scholarship, questions offer ways not only to ask for but also to give information (Russo and Wiberg, 2010), such as advertise personal achievements and - most relevantly - raise constituencyrelated issues (Bailer, 2011; Sebők et al., 2017; Wiberg and Koura, 1994).

Legislators in the UK use parliamentary questions for the substantive representation of 'visible minorities' (Saalfeld, 2011), women (Bird, 2005), and various religious groups (Kolpinskaya, 2017). Parties use parliamentary questions also to signal issue preferences: Green-Pedersen (2010) demonstrates a clear issue competition in parliamentary questions in Denmark, while in the Netherlands Otjes an Louwerse (2018) find that parties question ministers whose portfolios are salient to them. Additionally, research shows that legislators use parliamentary questions strategically to increase re-election chances. Blidook and Kerby (2011) demonstrate how Canadian legislators use questions to meet electoral motivations, in the UK, the usage of written questions is demonstrably influenced by the electoral context (Kellermann, 2016), and in Portugal, to improve re-election chances legislators take district problems into account when tabling questions (Borghetto et al., 2020). Importantly, MPs also adapt questioning to the incentives of electoral rules. Members of the European Parliament ask more questions if they are elected in candidate centred electoral systems (Sozzi, 2016). In Hungary's mixedmember electoral system SMD MPs and list MPs who are running in SMDs ask significantly more locally oriented questions than legislators not competing in the districts (Chiru, 2015; Sebők et al., 2017). 


\section{Agricultural policy}

The rural-urban cleavage is one of the most basic political divides (Lipset and Rokkan, 1967). Although cleavage politics have transformed and are now more based on values, traditional cleavages shape the new divisions (Kriesi, 1998). The rural-urban divide now represents geographic differences: a segregation of prospering cities and the declining periphery (Deegan-Krause, 2007; Ford and Jennings, 2020). Differences in social structural status, employment as well as sociocultural values and beliefs result in differences in attitudes towards domestic social issues (Kelly and Lobao, 2019), economic development (Harriss and Moore, 2017), political engagement (Thananithichot, 2012), the level of euroscepticism (Schoene, 2019), and importantly, political preferences (Clem and Craumer, 2002; Evans, 2006; Mcgrane et al., 2016; Rodden, 2019).

There is research showing that the legislators' behaviour reflects the geographical status of their districts. For instance, MPs from constituencies farther away from the capital are less likely to attend votes (Willumsen, 2019) and spend more time with casework in the UK (Wood and Young, 1997), and consider constituency service as the most important part of their jobs in Iceland (Hlynsdóttir and Önnudóttir, 2018). The agricultural profile of the constituency affects assignments to the agriculture committee (Raymond and Holt, 2019), roll call behaviour (Sulkin and Swigger, 2008) and the agricultural focus of parliamentary questions (Papp, 2020).

Based on the above, this study tests that legislators who ask more agriculture questions in alignment with district preferences perform better at the consecutive elections $(H)$.

\section{The Hungarian case}

To investigate the research question, I select Hungary as a case. Although political parties are unpopular political institutions, Hungarian politics is overwhelmingly party-centred (Enyedi and Tóka, 2007). Parties organize centralized campaigns even in single-member districts (Papp and Zorigt, 2016), and voters are more likely to support or oppose public policy if party cues are present (Brader and Tucker, 2012). Although SMDs create incentives to a personal 
vote, the effect of legislator action on vote choice is unlikely. Hence, the case offers a strong test of the hypothesis.

Despite the exceptional party discipline in parliament (Ilonszki, 2007), Hungarian legislators commonly use parliamentary questions to represent district interests (Chiru, 2015; Sebők et al., 2017). Questions allow them to bring up problems specific to their constituencies and thematize issues that parties would otherwise not put on the parliamentary agenda. On average, agriculture is a salient issue in the Hungarian parliament. On Figure 1, the black line represents the number of agriculture interpellations between 1990 and 2014. For the sake of comparison, interpellations in other topics are also presented and drawn in grey. Clearly, as far as interpellations are concerned, agriculture is indeed amongst the most important issues on the agenda. ${ }^{1}$

Figure 1. The frequency of agricultural interpellations (1990-2014)

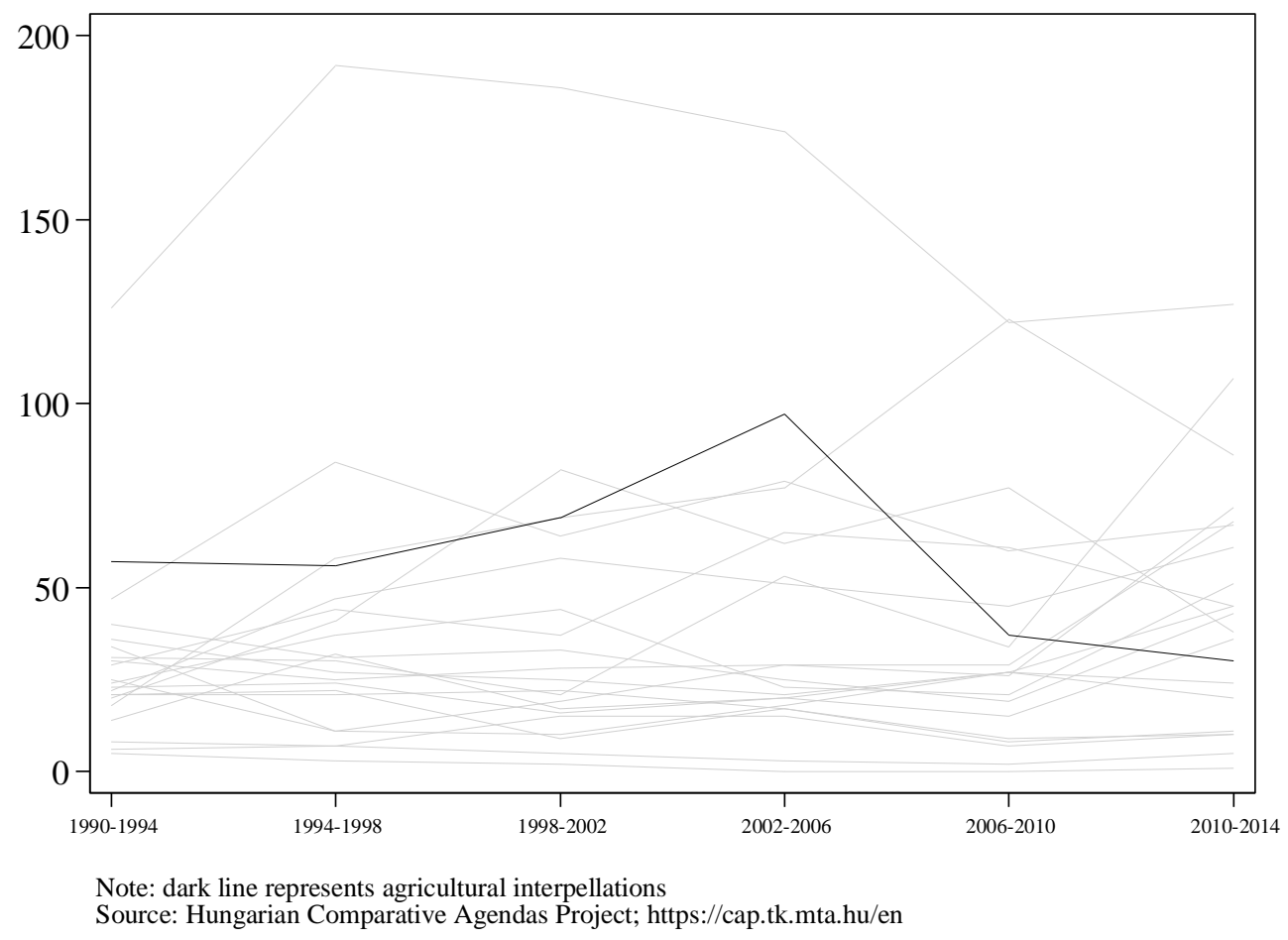

\footnotetext{
${ }^{1}$ The exact number of interpellations in the various fields is available in the Online Supplementary Material (Table 2).
} 
The analysis covers five consecutive elections from 1994 to 2010. During this time, Hungary has a three-tier mixed-member electoral system, where 176 MPs are elected from singlemember districts, and 210 legislators from regional and national party lists. Candidates may be simultaneously nominated on all tiers. This allows a number of strategies to emerge. Most prominently, besides SMD MPs, list MPs previously running in SMDs have also a strategic interest in constituency representation to stay on top of the SMD race for the next election (Carman and Shephard, 2007). The turnover amongst SMD candidates is moderate. The stable candidate pool enables MPs to strategically prepare for the next election already during the electoral term irrespective of what kind of mandate they currently hold. Therefore, this article takes into account not only the electoral performance of defending SMD MPs, but also that of list MPs nominated in SMDs.

\section{Data and variables}

\section{Key variables}

The dependent variable of the analysis is the first round vote share of MPs competing in SMDs at the next elections. The focus is on the interaction effect of two independent variables: (1) the number of agriculture interpellations, and (2) the percentage of agricultural population in the MP's district of candidacy.

Agriculture interpellations are those addressed to the Minister of Agriculture. Interpellations are aggregated to the MP-level indicating the number of agricultural interpellations asked by legislators during the respective electoral term. On the one hand, the majority of the MPs ask very few questions - if at all - in relation to agriculture. 86 (1990-1994) to 92 (1994-1998, 2006-2010) percent of MPs do not ask agricultural interpellations, and 44.5 (1990-1994) to 64.9 (1994-1998) percent of these did not submit any interpellations at all. On the other hand, there are a couple of experts (1.5 to 4 percent), who ask interpellations regarding agriculture only. About half of them are also members of the Agricultural Committee of the parliament, which further strengthens their status as specialists.

The agricultural profile of the constituency measures district demand. Occupational setup data from the Hungarian Statistical Office is used to describe the constituencies. It applies the 
International Standard Classification of Occupations (ISCO-88) ${ }^{2}$, which - most relevantly registers citizens above 15 years of age who make a living from agriculture and fishing ('skilled agricultural and fishery workers'). To every MP the share of agricultural population in their district of candidacy is assigned. Using district characteristics to proxy district demand is consistent with both American (Cameron et al., 1996; Hutchings et al., 2004) and European scholarship (Borghetto et al., 2020; Costa and Poyet, 2016; Däubler, 2018; Saalfeld, 2011). Looking at the whole period, the size of agricultural population living in the constituencies varies between 0 and 11.6 percent. These figures indicate that the agricultural population accounts to the lesser part of the total population. As the distribution of the agricultural population is heavily skewed to the left, the analysis uses the log-transformed version of the variable ${ }^{3}$.

\section{Control variables}

Most importantly, I control for the district level value of the regional list party vote share, to separate the 'normal vote' which the candidate receives because she is nominated by a certain party, from the personal vote that is due to her personal characteristics and record. This variable absorbs general tendencies in the overall party popularity as well as constituencyspecific effects. It is, of course, expected that the party vote share explains an overwhelmingly large portion of variation in the individual level vote share. ${ }^{45}$

\footnotetext{
${ }^{2}$ http://www.ilo.org/public/english/bureau/stat/isco/isco88/publ3.htm

${ }^{3}$ In the case of SMDs with no agricultural population, I take the natural log of 0.00001 in order to keep these districts in the sample. Figures 1, 2 and 3 in the Online Supplementary Material show the yearly distribution of the dependent and independent variables.

${ }^{4}$ One should keep in mind that it often happens that some SMD candidates do not have their parties competing on the regional list tier. Consequently, only those candidates are taken into account whose parties successfully nominated party lists in the respective regions.

${ }^{5}$ Adding party vote share to the model introduces the possibility of post-treatment bias. Agricultural interpellations (independent variable) may not only improve the performance of the legislators themselves (dependent variable) but their respective parties' vote share on the regional party list (control variable). Currently there is no commonly acceptable statistical fix for this problem. Excluding party vote share from the analysis leads to omitted variable bias: overall party popularity and constituency-specific characteristics will remain uncontrolled. Although there is no research addressing this specific problem, contextual knowledge suggests that due to the strong party-centeredness of Hungarian politics, the effect of the individual legislators' actions on the party vote is negligible. Therefore, it is to assume that the effect of the omitted variable bias on the model
} 
As to further district characteristics, I include voting turnout and electoral competition at the respective election. The rationale behind controlling for electoral turnout lies in the assumption that citizens of urban and rural areas participate with a different likelihood, which in the end influences how their preferences are reflected in the electoral performance of individual candidates. The literature argues that in less concentrated (i.e. rural) areas the stronger interpersonal bonds create - through consensus on norms - 'social pressure' to participate (Hoffman-Martinot, 1994; Overbye, 1995). In Hungary, there is a U-shape relationship between settlement size and voting intentions: citizens in Budapest and in the smallest settlements are the most likely to vote, while turnout in smaller cities and larger villages is lower (Kmetty and Tóth, 2011). Electoral competition - measured by the number of candidates running in the constituency - controls for how many parts the district vote is split up to. Naturally, the larger the competition the smaller the expected vote share of each candidate.

Among MP-level variables the model accounts for political positions, legislative experience and party affiliations. With regard to political positions two seem particularly important. Mayors are expected to receive a larger share of votes due to their local visibility. Arguably, local background serves as a heuristic that helps voters assess candidate quality (Cox, 1997; Tavits, 2010). Cabinet positions in Hungary also borrow visibility to legislators, making ministers to perform better at the elections.

As to legislative experience, SMD incumbency and tenure are both controlled for. The incumbency advantage is one of the most discussed topics in the personal vote literature. Incumbents systematically outperform challengers due to - among others - the campaign value of incumbency (Benoit and Marsh, 2008), direct office holder benefits (Hirano and Snyder, 2009), visibility (Cain et al., 1987; Klingemann and Wessels, 2001), and constituency service (King, 1991). Similarly, the larger the number of electoral terms legislators serve in parliament (regardless of mandate type), the more visible they become, the more experience they gather in successful campaigning, and the better equipped they are to attend the tasks of

outweighs that of the post-treatment bias. Still, one has to keep in mind the possibility of post-treatment bias as well. 
an MP. Thus, just like incumbency, tenure (i.e. the number of electoral terms served as a legislator in any type of seat) is also expected to improve the chances of re-election.

Last, but not least, there is a difference between parties in how their candidates exploit their potential to gather votes. However, in a longitudinal study, it is difficult to control for the party variable because of the turbulence that characterises the Hungarian party system during the respective period: several parliamentary parties disappeared, new ones emerged, and formed various electoral coalitions. To sort out the effect of the political party, two variables are included into the models. First, I distinguish between government and opposition parties. Earlier research suggests that Hungarian voters evaluate government parties on the basis of their performance during the previous electoral terms, and due to excessive expectations of the governments' economic performance, a substantial share of the vote is a protest against the previous government (Karácsony, 2006; Rose, 1992).

The second variable capturing the effect of party affiliation accounts for the difference between dominant parties, such as MSZP and Fidesz, and the rest. Within the greatest part of the period under investigation, these two parties dominated district level electoral competition. Furthermore, as strategic votes go to larger parties in SMDs in mixed electoral systems (Bawn, 1999; Karp et al., 2002; Klingemann and Wessels, 2001), controlling for the dominant party effect also captures strategic voting. While government candidates are expected to receive a smaller share of the votes, being a candidate of a dominant party is a potential vote attractor irrespective of government status.

\section{Results}

To test the effect of the legislators' agriculture-related parliamentary activity on their vote share conditional upon the agricultural profile of their districts, I run OLS regression models separately for the five elections. Each model controls for an interaction between interpellations and the agricultural profile of the constituency. The dataset contains all legislators running in SMDs. As in some cases, multiple MPs compete in the same SMD, standard errors are clustered by constituencies. Figure 2 summarizes the relevant results for 
the five models ${ }^{6}$. The vertical line at zero represents non-effect: effects with confidence intervals containing zero are not statistically significant.

Figure 2. The effects of agricultural interpellations, agricultural population and their interaction on vote share (CI: $95 \%)$
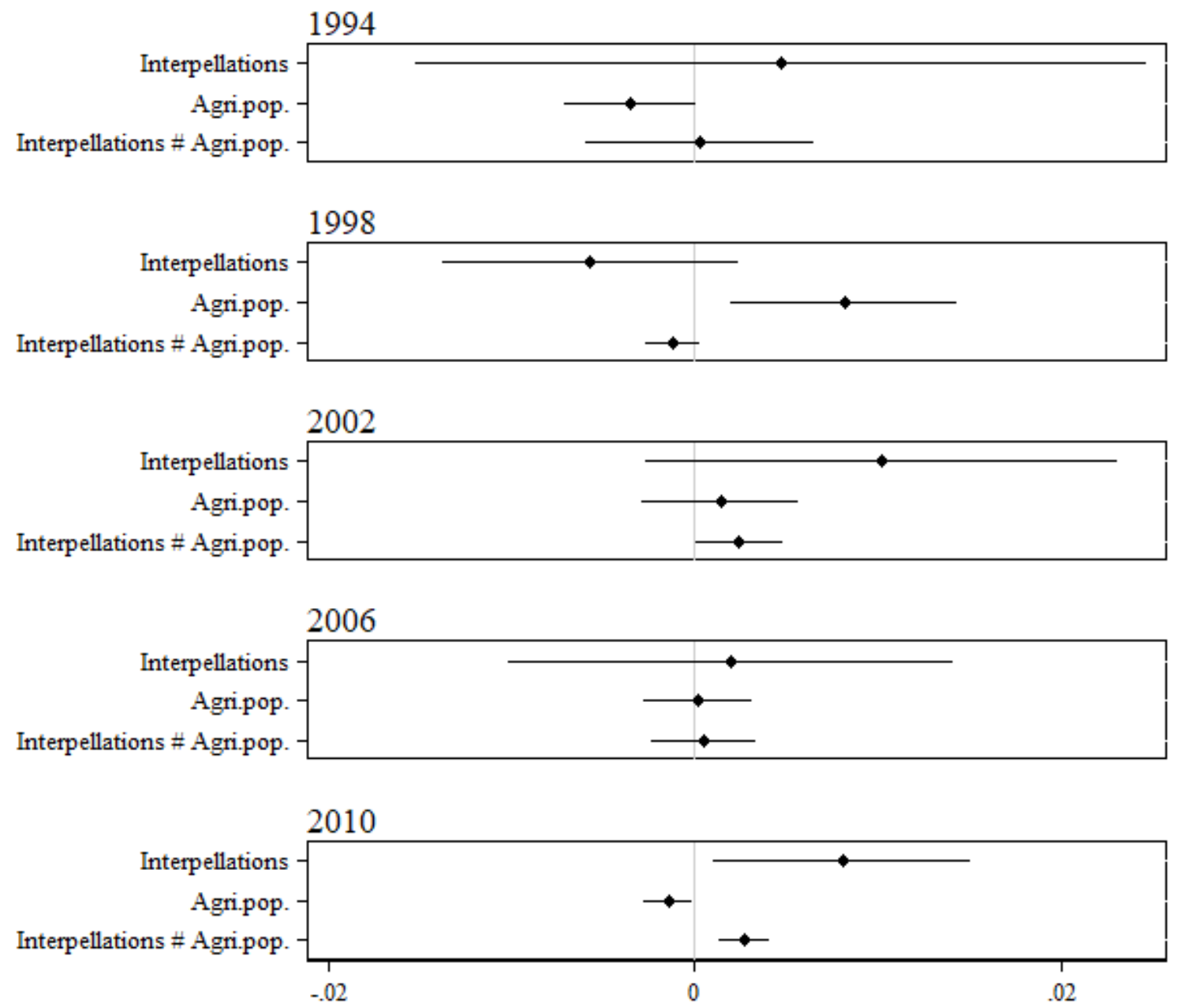

Results from the five elections reveal a mixed picture. The interaction between interpellations and district profile is only significant in two instances: 2002 and $2010^{7}$. Figure 3 shows the

\footnotetext{
${ }^{6}$ For the full models see the Online Supplementary Material (Table 4).

${ }^{7}$ Sample sizes at the five elections are between 177 and 244. Admittedly, the sample size is not ideal for testing interaction effects. Hence, to show that the effects are not only significant, but also more meaningful for the 2002 and 2010 elections, Figure 4 in the Online Supplemental Material visualizes the estimated vote share over the number of agricultural interpellations and the agricultural profile of the district. As all figures show estimated
} 
effect of the number of agricultural interpellations on MP vote share conditional upon the agricultural profile of the districts for 2002. Effects for 2010 are very similar; hence, the relevant graph is not displayed here. Darker lines on the figure represent districts with a larger agricultural population. In the cases of agricultural districts (i.e. the darkest lines on the top), the increasing number of interpellations represent an increasing match of district interests and legislator behaviour. The better this match is (i.e. the larger the number of agricultural interpellations), the larger the expected vote share. In the most agricultural constituency, 10 more interpellations (which is the maximum number of agricultural interpellations in 2002) increase vote share by 5.5 percentage points (from 36.6 to 42.1 percent). This is not necessarily a large effect, but may be decisive in close races. Conversely, in the case of the most urban districts (the lightest shades on the bottom), the increasing number of agricultural interpellations quickly decreases expected vote share. A 10-interpellation increase in a district with no agricultural population causes the vote share to drop from 35.3 to 18.1 percent.

Figure 3. The estimated vote share over the number of agricultural interpellations and the agricultural profile of the district in 2002

vote shares over the same range of interpellations, they are directly comparable. Figures reveal that the effect of agricultural interpellations is substantively larger in 2002 and 2010 than in other election years. The difference stands out especially in more urban districts (see lighter shades). 


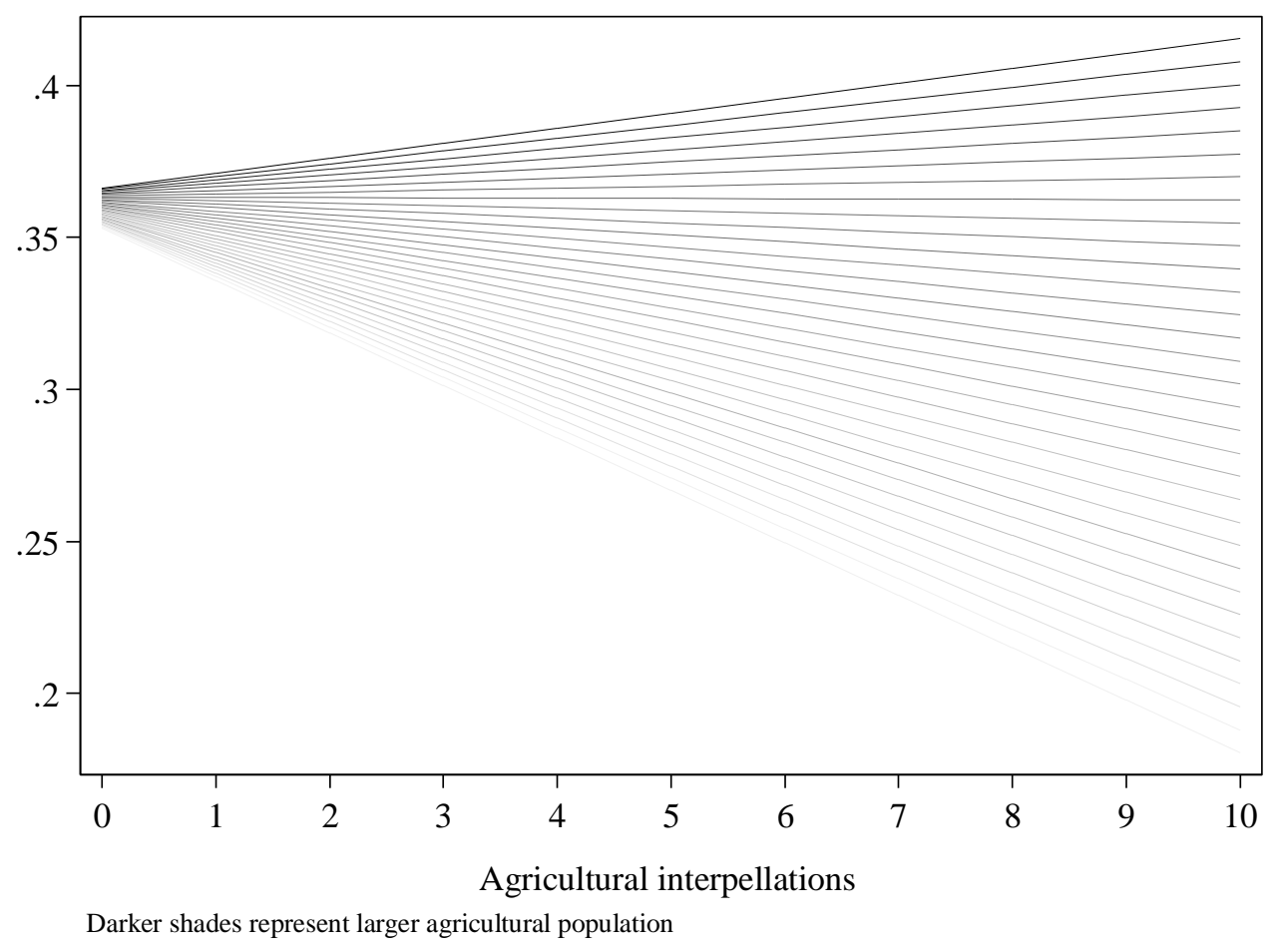

\section{Discussion}

Regression estimates support the hypothesis only for two elections: 2002 and 2010. In these cases, legislators who ask more agriculture questions in alignment with district preferences perform better at the next elections. At the same time, the analysis also reveals that interpellations related to the agriculture worsen the performance of MPs from urban constituencies.

The results raise the question of why we find evidence for the hypothesis at one election, and not at another. Why are 2002 and 2010 different from other elections? The answer probably lies, on the one hand, in the salience of the issue in 2002, and the unique political situation in 2010 on the other. Starting with 2002, the issue of agriculture was highly important due to the EU accession negotiations. Agriculture was the most controversial topic during the process which started in 1998, and concluded in December 2002. At the time of the elections, in April, negotiations were still open, and the effect of accession on the agricultural sector was far from clear yet. The stake of the deal was the amount of subsidy Hungarian farmers receive after accession. Agricultural interpellations, although remaining overwhelmingly local, 
focused on intervention prices, SAPARD ${ }^{8}$ aid, the Hungarian government's negotiation strategy, as well as post-accession prognosis. Importantly, in 2011, agriculture was prioritized as a policy issue on the media agenda (Tóth and Török, 2002), which only rarely happens on the national scale, and which brought voter attention to the issue. At the same time, the limelight on agriculture could divert attention away from issues relevant for more urban areas. As a result, voters in urban districts became more attentive to their legislators pursuing goals highly irrelevant for the constituency.

The 2010 elections represent a whole different story. By 2002, Hungarian politics was dominated by two parties creating a two-block system (Tóka and Popa, 2013). The 2006 general election results fit into this picture: the conservative Fidesz ${ }^{9}$ and the socialist MSZP ${ }^{10}$ won 59.8 percent of the seats in parliament. The distribution of SMD mandates across parties is also quite balanced: Fidesz brought in 32.4 percent $^{11}$ of the seats, while MSZP reached57.9 percent. Together with SZDSZ ${ }^{12}$, MSZP formed a government with a 54.4 percent majority. The popularity of the Socialists began its decline in September 2006 after a private speech of Prime Minister Ferenc Gyurcsány was leaked to the press. In this speech he admits that they lied to the citizens and did not achieve anything of significance during their previous term in government between 2002 and 2006. While polls before the 2006 elections measured the two parties neck and neck (35 - 35 percent) within the whole electorate, by 2010 Fidesz kept a steady 35 percent, and MSZP scored 15 percent or less. Eventually, MSZP received 15.3 percent of the seats (winning in only 2 SMDs), and Fidesz - KDNP won a majority that posttransition Hungary has never seen before (68 percent). The coalition parties together filled in 173 SMD seats out of 176.

Situations like this very much support the appearance of the personal vote. When voters leave a party in large quantities, the candidates with their local embeddedness and visibility play a larger role in influencing the SMD result. Trying to balance their decreasing popularity,

\footnotetext{
${ }^{8}$ Special Accession Programme for Agricultural and Rural Development

${ }^{9}$ Fidesz - Magyar Polgári Szövetség (Fidesz - Hungarian Civic Alliance)

${ }^{10}$ Magyar Szocialista Párt (Hungarian Socialist Party)

${ }^{11}$ Fidesz's seat share together with KDNP's (Kereszténydemokrata Néppárt; Christian Democratic People's Party) was 38.6 percent. The two parties nominated joint candidates and party lists at the 2006 elections. Pollsters do not measure KDNP separately.

${ }^{12}$ Szabad Demokraták Szövetsége (Alliance of Free Democrats)
} 
parties pursue personalized campaigns and appeal to the personal vote. As a consequence, voters start to assess the candidates on their own merits independent of party affiliations. Indeed, the effect of the party vote on the individual MPs' vote share in 2010 is one of the lowest in the period after the transition. Supporting this argument, we can see that there is a difference in how agricultural questions affect government and opposition MPs' vote shares. Figure 4 shows that while in the case of government MPs (Socialists) agricultural interpellations earn extra votes in agricultural districts, such effects are smaller for opposition MPs (see the slope of darker lines). Interestingly, the price of mismatch is considerable in both cases. Voters punish both government and opposition MPs when they focus on agriculture in primarily urban districts.

Figure 4. The estimated vote share over the number of agricultural interpellations conditional upon the agricultural profile of the district in 2010 across government and opposition parties
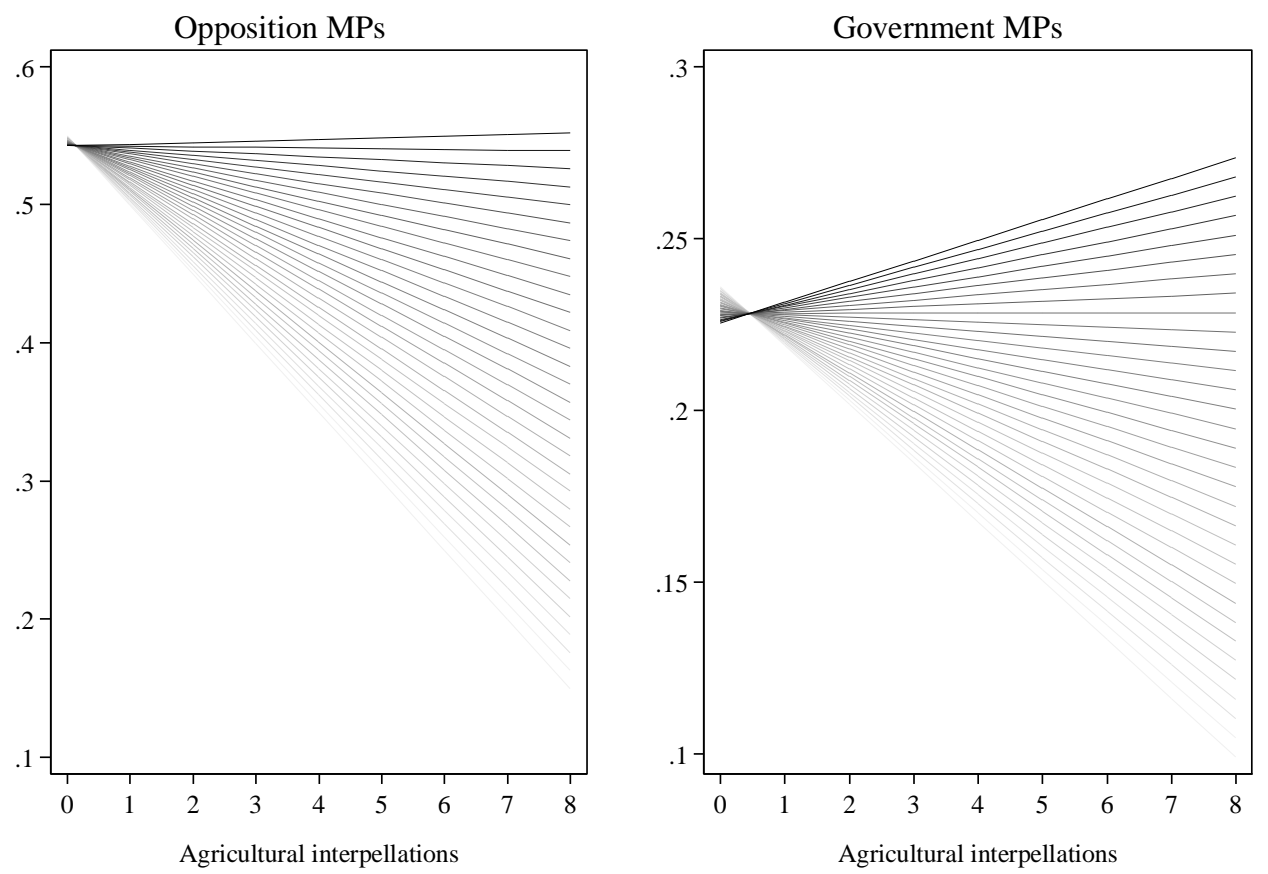

Darker shades represent larger agricultural population

\section{Conclusion}

The question this article seeks answer to is whether or not the representation of agricultural interests in parliament pays off at the next elections. I tested the effect of the number of agricultural interpellations on the Hungarian legislators' vote share, and expected that 
legislators who ask more agriculture questions in alignment with district preferences perform better at the next elections.

The regression analysis concludes with mixed results. The congruence between agricultural interests and agricultural questioning has a clear positive effect in 2002 and 2010. At these elections, while more interpellations are rewarded in rural districts, legislators who engage in agricultural questioning in constituencies where the issue of agriculture is not salient face a considerable disadvantage. Results indicate that the cost of a mismatch (i.e. asking agricultural interpellations) in urban areas is larger than that of a mismatch (i.e. asking no agricultural interpellations) in rural districts. In other words, MPs can lose a lot of votes by asking agricultural interpellations in the wrong district, while not submitting interpellations where it would matter does not result in similar vote loss.

Importantly, legislators must be generally active in parliament to gain re-selection and reelection (Papp and Russo, 2018), but they also have to strategize on the contents of their activities not only to gain votes but also to avoid substantial vote loss. The likely reason behind the findings is two-fold. One the one hand, the share of people living from agriculture is comparatively low. Even in the most rural district, agriculture ensures the living of only 11.6 percent of the people. Thus, agricultural interpellations can only increase vote share so much. Parliamentary action could increase vote share with a larger magnitude in more rural areas. More importantly, the opportunity cost of redundant parliamentary action is high. In the most urban districts, the smaller vote share is not necessarily due to the representation of agricultural interests, but because other important issues may remain unresolved. In other words, these figures are the result of the lack of interest representation in another - probably more relevant issue - rather than the representation of redundant interests. Advocating the wrong issue may rapidly alienate voters by painting the picture of out of touch legislators who ignore the constituency angle of their work, and pursue the representation of alternative interests.

Based on the results, two elections (2002 and 2010) were particularly important regarding the role of agriculture-related parliamentary activities. I argue that the circumstances of the elections put more emphasis on issue representation. EU accession negotiations provided the context to the elections in 2002, with agriculture being the most controversial issue. The results of the negotiation could have very well influenced the life of farmers for the worse, 
making agriculture an extremely salient topic. In 2010, the freefall of the government's popularity increased the candidates' roles in gathering votes, which allowed issue representation as candidate behaviour to gradually affect election results.

Findings, of course, have their limitations. First, there is an underlying assumption about the visibility of interpellations. In fact, we have no data about whether or not information from the interpellations reaches voters and if it does whether or not voters use them to make voting decisions. Second, even if interpellations do not capture the voters' attention, they may serve as proxy for an underlying third variable such as policy expertise, or other - unmeasured activities representing the interests of the agricultural population. Third, as being the most powerful tool of government control in parliament, and as being limited in numbers due to time restrictions, interpellations are subjects to strict party control. Therefore, representing an issue through interpellations is not primarily an expression of the MP's preferences, but rather a decision of the party leadership. However, it is also the party's interests to select experts and legislators from agricultural districts for this task simply to increase or stabilize their support in the constituency. Keeping all these limitations in mind, however, the major takeaway from the analysis is that issue alignment matters in cases when the context creates favourable circumstances in the form of increasing issue salience or increasing attention to candidate behaviour, and that the legislators may have to pay a higher price for ill-calibrated issue representation than for inaction. 


\section{References}

Abramowitz AI (1988) Explaining Senate Election Outcomes. American Political Science Review 82(2): 385-403. DOI: 10.2307/1957392.

Alvarez RM, Nagler J and Bowler S (2000) Issues, Economics, and the Dynamics of Multiparty Elections: The British 1987 General Election. The American Political Science Review 94(1): 131-149. DOI: 10.2307/2586385.

Ansolabehere S and Jones PE (2010) Constituents' Responses to Congressional Roll-Call Voting. American Journal of Political Science 54(3): 583-597. DOI: 10.1111/j.15405907.2010.00448.x.

Bailer S (2011) People's Voice or Information Pool? The Role of, and Reasons for, Parliamentary Questions in the Swiss Parliament. The Journal of Legislative Studies 17(3): 302-314.

Barro R (1973) The control of politicians: An economic model. Public Choice 14(1): 19-42.

Bawn K (1999) Voter Responses to Electoral Complexity: Ticket Splitting, Rational Voters and Representation in the Federal Republic of Germany. British Journal of Political Science 29(03): 487-505. DOI: null.

Benoit K and Marsh M (2008) The Campaign Value of Incumbency: A New Solution to the Puzzle of Less Effective Incumbent Spending. American Journal of Political Science 52(4): 874-890.

Bird K (2005) Gendering Parliamentary Questions. The British Journal of Politics and International Relations 7(3). SAGE Publications: 353-370. DOI: 10.1111/j.1467856X.2005.00196.x.

Blidook K and Kerby M (2011) Constituency Influence on 'Constituency Members': The Adaptability of Roles to Electoral Realities in the Canadian Case. The Journal of Legislative Studies 17(3): 327-339.

Borghetto E, Santana-Pereira J and Freire A (2020) Parliamentary Questions as an Instrument for Geographic Representation: The Hard Case of Portugal. Swiss Political Science Review 26(1): 10-30. DOI: 10.1111/spsr.12387.

Bovitz GL and Carson JL (2006) Position-Taking and Electoral Accountability in the U.S. House of Representatives. Political Research Quarterly 59(2). [University of Utah, Sage Publications, Inc.]: 297-312.

Brader T and Tucker JA (2012) Following the Party's Lead: Party Cues, Policy Opinion, and the Power of Partisanship in Three Multiparty Systems. Comparative Politics 44(4). DOI: $10.5129 / 001041512801283004$.

Bussing A, Patton W, Roberts JM, et al. (2020) The Electoral Consequences of Roll Call Voting: Health Care and the 2018 Election. Political Behavior. DOI: 10.1007/s11109020-09615-4. 
Cain B, Ferejohn J and Fiorina MP (1987) The Personal Vote: Constituency Service and Electoral Independence. Harvard University Press.

Cameron C, Epstein D and O'Halloran S (1996) Do Majority-Minority Districts Maximize Substantive Black Representation in Congress? American Political Science Review 90(4): 794-812. DOI: $10.2307 / 2945843$.

Canes-Wrone B, Brady DW and Cogan JF (2002) Out of Step, out of Office: Electoral Accountability and House Members' Voting. The American Political Science Review 96(1): 127-140.

Carey JM (2007) Competing Principals, Political Institutions, and Party Unity in Legislative Voting. American Journal of Political Science 51(1): 92-107. DOI: 10.1111/j.15405907.2007.00239.x.

Carman C and Shephard M (2007) Electoral Poachers? An Assessment of Shadowing Behaviour in the Scottish Parliament. The Journal of Legislative Studies 13(4): 483496.

Carson JL, Koger G, Lebo MJ, et al. (2010) The Electoral Costs of Party Loyalty in Congress. American Journal of Political Science 54(3). [Midwest Political Science Association, Wiley]: 598-616.

Chiru M (2015) Rethinking constituency service: electoral institutions, candidate campaigns and personal vote in Hungary \& Romania. Central European University, Budapest.

Clausen AR (1973) How Congressmen Decide: A Policy Focus. Palgrave Macmillan.

Clem RS and Craumer PR (2002) Urban and Rural Effects on Party Preference in Russia: New Evidence from the Recent Duma Election. Post-Soviet Geography and Economics 43(1). Routledge: 1-12. DOI: 10.1080/10889388.2002.10641190.

Costa O and Poyet C (2016) Back to their roots: French MPs in their district. French Politics 14(4): 406-438. DOI: 10.1057/s41253-016-0014-5.

Costello R, Thomassen J and Rosema M (2012) European Parliament Elections and Political Representation: Policy Congruence between Voters and Parties. West European Politics 35(6): 1226-1248. DOI: 10.1080/01402382.2012.713744.

Cox GW (1997) Making Votes Count: Strategic Coordination in the World's Electoral Systems. Cambridge, U.K.; New York: Cambridge University Press.

Däubler T (2018) National policy for local reasons: how MPs represent party and geographical constituency through initiatives on social security. Acta Politica. DOI: 10.1057/s41269-018-0125-x.

Deegan-Krause K (2007) New dimensions of political cleavage. In: Dalton RJ and Klingemann H-D (eds) The Oxford Handbook of Political Behavior. Oxford: Oxford University Press. 
Enyedi Z and Tóka G (2007) The Only Game in Town: Party Politics in Hungary. In: Paul Webb \& Stephen White (Eds.) Party Politics in New Democracies. Oxford: Oxford University Press, pp. 147-178.

Eulau H and Karps PD (1977) The Puzzle of Representation: Specifying Components of Responsiveness. Legislative Studies Quarterly 2(3): 233-254.

Evans G (2006) The Social Bases of Political Divisions in Post-Communist Eastern Europe. Annual Review of Sociology 32. Annual Reviews: 245-270.

Ezrow L (2005) Are moderate parties rewarded in multiparty systems? A pooled analysis of Western European elections, 1984-1998. European Journal of Political Research 44(6): 881-898. DOI: 10.1111/j.1475-6765.2005.00251.x.

Fearon J (1999) Electoral Accountability and the Control of Politicians: Selecting Good Types versus Sanctioning Poor Performance. In: Adam Przeworski, Susan C. Stokes and Bernard Manin (Eds.) Democracy, Accountability, and Representation. New York: Cambridge University Press.

Ferejohn J (1986) Incumbent Performance and Electoral Control. Public Choice 50(1/3): 525.

Ford R and Jennings W (2020) The Changing Cleavage Politics of Western Europe. Annual Review of Political Science 23(1): 295-314. DOI: 10.1146/annurev-polisci-052217104957.

Green-Pedersen C (2010) Bringing Parties Into Parliament: The Development of Parliamentary Activities in Western Europe. Party Politics 16(3). SAGE Publications Ltd: 347-369. DOI: 10.1177/1354068809341057.

Harriss J and Moore M (2017) Development and the Rural-Urban Divide. Routledge.

Healy A and Malhotra N (2013) Retrospective Voting Reconsidered. Annual Review of Political Science 16(1): 285-306. DOI: 10.1146/annurev-polisci-032211-212920.

Hirano S and Snyder JM (2009) Using Multimember District Elections to Estimate the Sources of the Incumbency Advantage. American Journal of Political Science 53(2): 292-306. DOI: 10.1111/j.1540-5907.2009.00371.x.

Hlynsdóttir EM and Önnudóttir EH (2018) Constituency Service in Iceland and the Importance of the Centre-Periphery Divide. Representation 54(1). Routledge: 55-68. DOI: $10.1080 / 00344893.2018 .1467338$.

Hoffman-Martinot V (1994) Voter turnout in French municipal elections. In: Lopez-Nieto L (ed.) Local Elections in Europe. Barcelona: Institut de cie`nces politiques I socials, pp. $13-42$.

Hutchings VL, McClerking HK and Charles G-U (2004) Congressional Representation of Black Interests: Recognizing the Importance of Stability. The Journal of Politics 66(2): 450-468. DOI: 10.1111/j.1468-2508.2004.00159.x. 
Ilonszki G (2007) From Minimal to Subordinate: A Final Verdict? The Hungarian Parliament, 1990-2002. The Journal of Legislative Studies 13(1). Routledge: 38-58. DOI: $10.1080 / 13572330601165261$.

Karácsony G (2006) Árkok és légvárak. A választói viselkedés stabilizálódása Magyarországon. In: Gergely Karácsony (Ed.) A 2006-Os Országgyülési Választások. Elemzések És Adatok. Budapest: DKMKA, pp. 59-103.

Karp JA, Vowles J, Banducci SA, et al. (2002) Strategic voting, party activity, and candidate effects: testing explanations for split voting in New Zealand's new mixed system. Electoral Studies 21(1): 1-22. DOI: 10.1016/S0261-3794(00)00031-7.

Kellermann M (2016) Electoral Vulnerability, Constituency Focus, and Parliamentary Questions in the House of Commons. The British Journal of Politics and International Relations 18(1): 90-106. DOI: 10.1111/1467-856X.12075.

Kelly P and Lobao L (2019) The Social Bases of Rural-Urban Political Divides: Social Status, Work, and Sociocultural Beliefs. Rural Sociology 84(4): 669-705. DOI: 10.1111/ruso.12256.

Key VO (1966) The Responsible Electorate : Rationality in Presidential Voting, 1936-1960. New York: Random House.

King G (1991) Constituency Service and Incumbency Advantage. British Journal of Political Science 21(1): 119-128.

Kingdon JW (1989) Congressmen's Voting Decisions. Third edition. Ann Arbor: University of Michigan Press.

Kirkland JH and Harden JJ (2016) Representation, Competing Principals, and Waffling on Bills in US Legislatures. Legislative Studies Quarterly 41(3): 657-686. DOI: 10.1111/lsq.12132.

Klingemann H-D and Wessels B (2001) The Political Consequence of Germany's MixedMember System: Personalization at the Grass Roots? In: Shugart MS and Wattenberg MP (eds) Mixed-Member Electoral Systems. The Best of Both Worlds? Oxford: Oxford University Press, pp. 279-296.

Kmetty Z and Tóth G (2011) A politikai részvétel három szintje. In: Tardos R, Enyedi Z, and Szabó A (eds) Részvétel, Képviselet, Politikai Változás. Budapest: Demokrácia Kutatások Magyar Központja Alapítvány.

Kolpinskaya E (2017) Substantive Religious Representation in the UK Parliament: Examining Parliamentary Questions for Written Answers, 1997-2012. Parliamentary Affairs 70(1). Oxford Academic: 111-131. DOI: 10.1093/pa/gsw001.

Kriesi H (1998) The transformation of cleavage politics The 1997 Stein Rokkan lecture. European Journal of Political Research 33(2): 165-185. DOI: 10.1023/A:1006861430369.

Lin T-M, Enelow JM and Dorussen H (1999) Equilibrium in Multicandidate Probabilistic Spatial Voting. Public Choice 98(1/2): 59-82. 
Lipset SM and Rokkan S (1967) Party Systems and Voter Alignments: Cross-National Perspectives. Free Press.

Maestas C (2000) Professional Legislatures and Ambitious Politicians: Policy Responsiveness of State Institutions. Legislative Studies Quarterly 25(4): 663-690. DOI: $10.2307 / 440439$.

Mansbridge J (2009) A “Selection Model” of Political Representation. Journal of Political Philosophy 17(4): 369-398.

Mayhew DR (1974) Congress: The Electoral Connection, Second Edition. Yale University Press.

Mcgrane D, Berdahl L and Bell S (2016) Moving Beyond the Urban/Rural Cleavage: Measuring Values and Policy Preferences Across Residential Zones in Canada. Journal of Urban Affairs. DOI: 10.1111/juaf.12294.

Miller WE and Stokes DE (1963) Constituency Influence in Congress. The American Political Science Review 57(1): 45-56.

Norris P (1997) The puzzle of constituency service. The Journal of Legislative Studies 3(2): 29-49.

Nyhan B, McGhee E, Sides J, et al. (2012) One Vote Out of Step? The Effects of Salient Roll Call Votes in the 2010 Election. American Politics Research 40(5). SAGE Publications Inc: 844-879. DOI: 10.1177/1532673X11433768.

Otjes S and Louwerse T (2018) Parliamentary questions as strategic party tools. West European Politics 41(2). Routledge: 496-516. DOI:

10.1080/01402382.2017.1358936.

Overbye E (1995) Making a case for the rational, self-regarding, 'ethical' voter... and solving the 'Paradox of not voting' in the process. European Journal of Political Research 27(3): 369-396. DOI: 10.1111/j.1475-6765.1995.tb00475.x.

Papp Z (2020) The Mandate Divide in Policy Representation: The Substantive Representation of Agricultural Interests in the Hungarian Parliament. Parliamentary Affairs. DOI: $10.1093 / \mathrm{pa} / \mathrm{gsaa} 002$.

Papp Z and Russo F (2018) Parliamentary Work, Re-Selection and Re-Election: In Search of the Accountability Link. Parliamentary Affairs 71(4): 853-867. DOI: $10.1093 / \mathrm{pa} / \mathrm{gsx} 047$.

Papp Z and Zorigt B (2016) Party-directed personalisation: the role of candidate selection in campaign personalisation in Hungary. East European Politics 32(4): 466-486. DOI: 10.1080/21599165.2016.1215303.

Raymond CD and Holt J (2019) Constituency Preferences and Assignment to Agriculture Committees. Parliamentary Affairs 72(1): 141-161. DOI: 10.1093/pa/gsy012.

Roberts A (2009) The Quality of Democracy in Eastern Europe: Public Preferences and Policy Reforms. 1 edition. Cambridge : New York: Cambridge University Press. 
Roberts A and Kim B-Y (2011) Policy Responsiveness in Post-communist Europe: Public Preferences and Economic Reforms. British Journal of Political Science 41(4): 819839. DOI: $10.1017 / \mathrm{S} 0007123411000123$.

Rodden JA (2019) Why Cities Lose: The Deep Roots of the Urban-Rural Political Divide. Hachette UK.

Rogers S (2017) Electoral Accountability for State Legislative Roll Calls and Ideological Representation. American Political Science Review 111(3). Cambridge University Press: 555-571. DOI: 10.1017/S0003055417000156.

Rosas G, Shomer Y and Haptonstahl SR (2015) No News Is News: Nonignorable Nonresponse in Roll-Call Data Analysis. American Journal of Political Science 59(2): 511-528. DOI: 10.1111/ajps.12148.

Rose R (1992) Escaping from Absolute Dissatisfaction. A Trial-And-Error Model of Change in Eastern Europe. Journal of Theoretical Politics 4(4): 371-393.

Russo F and Wiberg M (2010) Parliamentary Questioning in 17 European Parliaments: Some Steps towards Comparison. The Journal of Legislative Studies 16(2): 215-232.

Saalfeld T (2011) Parliamentary Questions as Instruments of Substantive Representation: Visible Minorities in the UK House of Commons, 2005-10. The Journal of Legislative Studies 17(3): 271-289.

Schoene M (2019) European disintegration? Euroscepticism and Europe's rural/urban divide. European Politics and Society 20(3). Routledge: 348-364. DOI: 10.1080/23745118.2018.1542768.

Schofield N (2004) Equilibrium in the Spatial 'Valence' Model of Politics. Journal of Theoretical Politics 16(4): 447-481.

Sebők M, Molnár C and Kubik BG (2017) Exercising control and gathering information: the functions of interpellations in Hungary (1990-2014). The Journal of Legislative Studies 23(4): 465-483. DOI: 10.1080/13572334.2017.1394734.

Serra G and Moon D (1994) Casework, Issue Positions, and Voting in Congressional Elections: A District Analysis. The Journal of Politics 56(1): 200-213. DOI: $10.2307 / 2132353$.

Söderlund P (2008) Retrospective Voting and Electoral Volatility: A Nordic Perspective. Scandinavian Political Studies 31(2): 217-240. DOI: 10.1111/j.14679477.2008.00203.x.

Sorace M (2018) The European Union democratic deficit: Substantive representation in the European Parliament at the input stage. European Union Politics 19(1). SAGE Publications: 3-24. DOI: 10.1177/1465116517741562.

Sozzi F (2016) Electoral foundations of parliamentary questions: evidence from the European Parliament. The Journal of Legislative Studies 22(3). Routledge: 349-367. DOI: 10.1080/13572334.2016.1202650. 
Sulkin T and Swigger N (2008) Is There Truth in Advertising? Campaign Ad Images as Signals about Legislative Behavior. The Journal of Politics 70(1). The University of Chicago Press: 232-244. DOI: 10.1017/S0022381607080164.

Sullivan JL, Shaw LE, McAvoy GE, et al. (1993) The Dimensions of Cue-Taking in the House of Representatives: Variation by Issue Area. The Journal of Politics 55(4): 975-997. DOI: 10.2307/2131944.

Tavits M (2010) Effect of Local Ties On Electoral Success and Parliamentary Behaviour The Case of Estonia. Party Politics 16(2): 215-235.

Thananithichot S (2012) Political engagement and participation of Thai citizens: the ruralurban disparity. Contemporary Politics 18(1). Routledge: 87-108. DOI: 10.1080/13569775.2012.651274.

Thomassen J and Andeweg RB (2004) Beyond collective representation: individual members of parliament and interest representation in the Netherlands. The Journal of Legislative Studies 10(4): 47-69.

Tóka G (2002) Issue Voting and Party Systems in Central and Eastern Europe. In: Fuchs D, Roller E, and Weßels B (eds) Bürger Und Demokratie in Ost Und West: Studien Zur Politischen Kultur Und Zum Politischen Prozess. Festschrift Für Hans-Dieter Klingemann. Wiesbaden: VS Verlag für Sozialwissenschaften, pp. 169-185. DOI: 10.1007/978-3-322-89596-7_9.

Tóka G and Popa S (2013) Hungary. In: Sten Berglund, Joakim Ekman, Kevin DeeganKrause \& Terje Knutsen (Eds.) The Handbook of Political Change in Eastern Europe. 3rd ed. Cheltenham: Edward Elgar, pp. 291-338.

Tóth C and Török G (2002) Politikai napirend, 2001: kiegyenlítettebb tematizációs verseny a választások előtt (Political agenda, 2001: A more balances thematizing competition befor the elections). In: Kurtán S, Sándor P, and Vass L (eds) Magyarország Politikai Évkönyve 2001-Röl (The Political Yearbook of Hungary from 2001). Budapest: DKMKA, pp. 167-188.

Verba S and Nie NH (1987) Participation in America: Political Democracy and Social Equality. Chicago: University of Chicago Press.

Wiberg M and Koura A (1994) The Logic of Parliamentary Questions. In: Matti Wiberg (Ed.) Parliamentary Control in Nordic Countries. Helsinki: Finnish Political Science Association, pp. 19-43.

Willumsen DM (2019) So far away from me? The effect of geographical distance on representation. West European Politics 42(3). Routledge: 645-669. DOI: 10.1080/01402382.2018.1530887.

Wood DM and Young G (1997) Comparing Constituency Activity by Junior Legislators in Great Britain and Ireland. Legislative Studies Quarterly 22(2). [Wiley, Comparative Legislative Research Center]: 217-232. DOI: 10.2307/440383. 
Woon J (2012) Democratic Accountability and Retrospective Voting: A Laboratory Experiment. American Journal of Political Science 56(4): 913-930. DOI: 10.1111/j.1540-5907.2012.00594.x. 